\title{
PILOT PROYEK PEMANFAATAN LAHAN PEKARANGAN UNTUK BUDIDAYA TANAMAN DALAM RANGKA UPAYA EFISIENSI BIAYA HIDUP KELUARGA DI DESA DENGGUNGAN BANYUDONO KABUPATEN BOYOLALI
}

\author{
Dibyo Iskandar ${ }^{1)}$ \\ Etty Indriani ${ }^{2)}$ \\ STIE Adi Unggul Bhirawa Surakarta
}

\begin{abstract}
Abstrak
Lahan tidur di Indonesia, sangat luas baik lahan pertanian yang beralih fungsi yang untuk sementara waktu belum difungsikan sesuai peruntukkan dan lahan pekarangan yang dibiarkan menganggur tidak diolah atau belum dimanfaatkan dengan baik. Padahal jika lahan tersebut dioptimalkan, pemanfaatannya dapat memberikan banyak hal yang positif misalnya mengurangi pengangguran,menambah supply bahan pangan dan lingkungan tidak terkesan kumuh dan sekaligus sebagai sarana untuk memenuhi kebutuhan rumah tangga dan peningkatan pendapatan keluarga. Yang berkaitan dengan kepemilkkan pribadi terutama lahan pekarangan jika diolah memiliki potensi dalam menyediakan bahan pangan keluarga, mengurangi pengeluaran rumah tangga untuk pembelian pangan yang menjadi ironi.dan permasalahan atau fenomena yang tidak disadari oleh sebagian besar masyarakat,yang ditandai masih banyak dijumpai kurang optimalnya pemanfaatan lahan pekarangan diantaranya belum membudaya budidaya pekarangan secara intensif, masih bersifat sambilan dan belum berorientasi pasar dan belum adanya program khusus dari petugas atau kader.

Tujuan pengabdian ini adalah memberikan motivasi kepada masyarakat demgan cara memberikan bukti nyata melalui Pilot Proyek pemanfaatan lahan pekarangan seluas kurang lebih 1000 meter dengan ditanami empat jenis sayuran yaitu bayam cabut, kangkung cabut kacang panjang dan terong setelah melihat bukti sehingga masyarakat bisa tertarik untuk memanfaatkan lahan miliknya untuk difungsikan dengan baik..Kegiatan pengabdian ini dilaksanakan di Desa Denggungan Kecamatan Banyudono Kabupaten Boyolali..

Hasil pengabdian ini menunjukkan bahwa peserta yang hadir bersedia membentuk kelompok yang terdiri bapak dan Ibu - ibu berkenan sebagai penggiat pengoptimalan lahan pekarangan melalui kesediaannya menggarap lahan pilot proyek secara suka rele dan bersedia membagikan hasil tanaman secara gratis kepada masyarakat pada awal pertama panen.
\end{abstract}

Kata kunci: lahan pekarangan, pilot proyek,penggiat,hasil,ketertarikan.

\section{A. Pendahuluan}

Dalam masyarakat perdesaan,yang sebagian besar bermatapencaharian sebagai petani ,masyarakat tersebut mempunyai banyak waktu luang antara musim tanam dan musim panen,disatu sisi masyarakat pedesaan mempunyai lahan pekarangan yang cukup luas yang kurang dikelola dengan baik.. Komitmen pemerintah untuk melibatkan rumah tangga dalam mewujudkan kemandirian pangan perlu diaktualisasikan dalam menggerakkan melalui pembudidyaan dan pemanfaatan lahan pekarangan secara optimal..

Optimalisasi pemanfaatan lahan pekarangan secara intensif dan extensif melalui pengelolaan sumberdaya alam lokal secara bijaksana, yang menjamin kesinambungan persediaannya dengan tetap memelihara dan meningkatkan kualitas, nilai dan keanekaragamannya. Penataan pekarangan, ditujukan untuk memperoleh manfaat yang sebesar-besarnya melalui pengelolaan lahan pekarangan secara intensif dan extensif bukan saja dari sisi ekonomi tetapi juga dari sisi lingkungan dengan tata letak sesuai dengan pemilihan komoditas.

Lahan pekarangan merupakan lahan terbuka yang terdapat di sekitar rumah tinggal. Lahan ini jika dipelihara dengan baik akan memberikan lingkungan yang menarik nyaman dan sehat serta menyenangkan sehingga membuat penghuninya betah tinggal di rumah. Pekarangan rumah dapat dimanfaatkan sesuai dengan selera dan keinginan. Misalnya 
dengan menanam tanaman produktif seperti tanaman hortikultura dan obat-obatan. Dengan menanam tanaman produktif di pekarangan akan memberi keuntungan ganda, salah satunya adalah kepuasan jasmani dan rohani. .

Pemanfaatan pekarangan dapat mendukung penyediaan aneka ragam pangan di tingkat rumah tangga, sehingga terwujud pola konsumsi pangan keluarga yang beragam, bergizi seimbang dan aman, dimana di pekarangan dapat ditanam berbagai jenis tanaman yang dibutuhkan sehari-hari seperti tanaman buah, sayuran, tanaman obat dan lain-lain . Untuk mendukung usaha pemenuhan pangan dan gizi keluarga, pemanfataan pekarangan saat ini lebih dititikberatkan pada usaha budidaya sayuran yang berumur relatif pendek sehingga dapat dengan segera dimanfaatkan untuk memenuhi kebutuhan keluarga atau dijual untuk menambah pendapatan keluarga. Rukmana (2009) mengemukakan bahwa lahan pekarangan dapat dijadikan asset berharga bagi pengembangan usahatani skala rumah tangga, oleh karena itu pemanfaatan lahan pekarangan dapat dijadikan basis usaha pertanian tanaman sayuran dalam rangka memberdayakan sumberdaya keluarga serta meningkatkan ketahanan pangan dan kecukupan gizi.

Bagi masyarakat perdesaan, pekarangan dapat dipandang sebagai lumbung hidup yang tiap musim diperlukan untuk mengatasi paceklik dan sekaligus merupakan pangkalan induk yang sewaktu-waktu dapat diambil manfaatnya apabila usaha tani di sawah atau tegalan mengalami bencana atau kegagalan akibat serangan hama atau penyakit, banjir, kekeringan dan bencana alam lain. Tanaman sayur merupakan contoh taman multifungsi. Di satu sisi tampilannya cukup memberikan kesan dan ketika dipanen dapat dimanfaatkan sebagai bahan pangan (Supriati dan Herliana, 2008).

Mewujudkan sistem pertanian terpadu di lahan pekarangan bukan merupakan hal yang mudah bagi masyarakat, tidak terkecuali rumah tangga petani. Sumber daya manusia yang ada dan terbatasnya informasi yang bisa sampai di pedesaan, merupakan salah satu faktor pendukungnya. Perhatian masyarakat terhadap pemanfaatan lahan pekarangan masih terbatas. Akibatnya pengembangan berbagai kreatifitas dan inovasi yang terkait dengan lahan pekarangan belum mencapai sasaran seperti yang diharapkan. Padahal dengan pemanfaatan lahan pekarangan untuk tanaman obat, tanaman pangan, hortikultura, ternak, ikan dan lainnya berpotensi dapat memenuhi kebutuhan keluarga. Disamping itu, pemanfaatan pekarangan juga berpeluang menambah penghasilan rumah tangga apabila dirancang dan direncanakan dengan baik (Mardiharini, 2011).

Mendasarkan beberapa potensi lahan pekarangan dan permasalahan di atas untuk mewujudkan ketahanan pangan keluarga, maka perlu mensosialisasikan bagaimana lebih mengoptimalkan lahan pekarangan menjadi sistem pertanian terpadu agar masyarakat atau rumah tangga petani sebagai masyarakat subsistem bisa merasakan langsung manfaatnya.

Metode

Sasaran pelatihan dengan percontohan untuk optimalisasi lahan pekarangan dengan budidaya tanaman sayuran di Desa Denggungan Kecamatan Banyudono Kabupaten Boyolali adalah masyarakat yang terdiri dari pengurus Lembaga Pemberdayaan Ekonomi Masyarakat Desa Pengurus Rukun Tetangga dan pemuka masyarakat dan relawan. Komitmen Pemerintah dalam pengembangan ketahanan pangan adalah intensifikasi lahan pekarangan, lahan tidur dengan mengoptimalkan fungsinya secara produktif .

Metode kegiatan yang dilakukan untuk tercapainya tujuan pengabdian kepada masyarakat ini adalah metode diskusi dan demonstrasi praktik langsung di lapangan yang didasari oleh evaluasi awal sebagai landasan untuk menentukan kemauan dan kemampuan pengetahuan kelompok sasaran mengenai pemanfaatan lahan pekarangan melalui optimalisasi lahan pekarangan dengan budidaya tanaman sayuran di lahan pilot proyek sebagai upaya untuk memberikan contoh nyata . 
Kegiatan Pengabdian Kepada Masyarakat di Desa Denggungan Kecamatan Banyudono dihadiri 24 peserta yang merupakan sukarelawan sebagai kader penggerak Pemberdayaan ekonomi desa.. Kegiatan Pengabdian diharapkan mampu mengubah perilaku masyarakat menjadi produktif melalui pengoptimalan seluruh suber daya yang dimiliki..Tahapan dalam Kegiatan pengabdian terdiri tahap pertama adalah menumbuhkan kemauan masyarakat ( Memotivasi ) dengan cara mengajak mereka ke kawasan lahan pekarangan produktif di Desa Ngesrep Kecamatan Ngempklak Kabupaten Boyolali, Kedua peningkatan kemampuan teknis pengolahan lahan pekarangan .Ketiga Implementasi pemanfaatan lahan pekarangan dengan mengolah dan menggarap lahan sebagai pilot proyek penanaman sayuran.Keempat Melakukan Pendampingan berkala kerja sama dengan pegawai dinas pertanian ( penduduk setempat).

\section{B. Hasil dan Pembahasan}

Pengabdian kepada masyarakat dengan pendekatan Pilot proyek pengolahan lahan pekarangan secara optimal dilaukan di Desa Denggungan Kecamatan Banyudono yang melibatkan 24 peserta yang secara suka rela menyediakan diri sebagai kader dalam memotivasi masyarakat untuk membudidayakan pekarangannya untuk ditanami khususnya sayuran.. Pertemuan dengan anggota peserta untuk menyatukan persepsi dan langkah langkah kegitatan dalam mempersiapkan lahan dan tahapan pengolahan lahan yang telah disediakan salah satu masyarakat untuk dijadikan lahan percontohan pemanfataatan lahan pekarangan secara optimal untuk memberikan bukti nyata kepada masyarakat Desa Denggungan dengan melalui pilot proyek..Tahapan Kegiatan yang dilakukan meliputi penyediaan lahan garapan dan pengukuran lahan pekarangan yang akan digarap,pemetakan lahan sesuai dengan peruntukan tanaman,penyemprotan gulma tanaman yaitu rumput supaya mati,pembakaran gulma, penglahan lahan dengan traktor dan dicangkul, penggemburan dengan memberikan pupuk kompos, pembedengan sesuai dengan ukuran ideal. Menentukan kelompok pengerjaan sesuai dengan paket jenis tanaman masing - masing kelompok sebagai penanggung jawab. Penataan lahan pekarangan dilakukan dengan bedengan atau ditanam langsung. Beberapa benih dan bibit sayuran yang ditanam di lahan pekarangan rumah tangga diantaranya adalah kangkung darat,bayam cabut,terong dan kacang panjang.Pada dasarnya pengerjaan awal lahan garapan tahapan maupun secara teknik metode, atau caranya relatif sama.

Garapan lahan pekarangan selanjutnya disesuaikan dengan spesifikasi dan ketentuanketentuan berdasarkan kesepakatan yang berlaku.

Tabel 4.1. Jenis Tanaman dan Luas Lahan Pekarangan sebagai Pilot Proyek

\begin{tabular}{|l|l|l|c|}
\hline No & Jenis Tanaman & Luas Lahan & Proporsi $(\%)$ \\
\hline 1 & Kangkung Darat & $(10 \times 20 \mathrm{M})=200 \mathrm{M}$ & $18 \%$ \\
\hline 2 & Bayam Cabut & $(10 \times 15 \mathrm{M})=150 \mathrm{M}$ & $13,53 \%$ \\
\hline 3 & Terong & $(18 \times 20 \mathrm{M})=360 \mathrm{M}$ & $32,47 \%$ \\
\hline 4 & Kacang Panjang & $(20 \times 20 \mathrm{M})=400 \mathrm{M}$ & $36 \%$ \\
\hline & Total luas lahan & $1110 \mathrm{M}$ & $100 \%$ \\
\hline
\end{tabular}

Sumber : Data diolah

Berdasarkan Tabel 4.1 menunjukkan bahwa luas lahan pekarangan sebagai lahan Pilot Proyek penanaman sayuran di Desa Denggungan Kecamatan Banyudono Kabupaten Boyolali akan ditanami empat jenis sayuran yaitu : Sayuran Kangkung Darat seluas 200 M atau $18 \%$ dari total luas lahan ,sayuran Bayam Cabut seluas $150 \mathrm{M}$ atau 13,53\% dari total luas lahan ,sayuran Terong seluas $360 \mathrm{M}$ atau seluasr $32,47 \%$ dari luas totallahan dan sayuran Kacang Panjang seluas $400 \mathrm{M}$ atau seluas $36 \%$ daritotal luas lahan. 
Pembagian luas lahan pekarangan sebagai lahan pilot proyek tanaman sayuran berdasarkan diskusi dan didasarkan atas hasil kesepakatan dengan warga peserta sejumlah 24 orang secara rasional mendasarkan berbagai faktor yang berkaitan dengan luas lahan, tingkat kesulitan dan intensitas operasional dalam penanaman dan pemeliharaan jenis sayuaran dan pengolahan lahan pekarangan dalam pilot proyek pemanfaatan lahan pekarangan yang dioptimalkan dengan budidaya tanaman sayuran, berdasarkan kesepakatan diperoleh hasil pembagian kelompok berdsar jenis tanaman sayuran,luas lahan dan jumlah penanggung jawab sebagaimana yang tertuang di Tabel 4.2. sbb:

Tabel 4.2. Faktor Pembagian Kelompok Dan Personil Penanggung Jawab Penggarapan Lahan Pilot Proyek

\begin{tabular}{|l|l|l|l|}
\hline & Jenis tanaman dan Luas Lahan & $\begin{array}{l}\text { Tingkat } \\
\text { Intensitas } \\
\text { garapan }\end{array}$ & $\begin{array}{l}\text { Jumlah } \\
\text { penanggung } \\
\text { jawab }\end{array}$ \\
\hline 1 & Kangkung darat $(200 \mathrm{M})$ & Tinngi & 5 orang \\
\hline 2 & Bayam cabut $(150 \mathrm{M})$ & Sangat tinggi & 5 orang \\
\hline 3 & Terong $(360 \mathrm{M})$ & Sedang & 6 orang \\
\hline 4 & Kacang P $(400 \mathrm{M})$ & Tinggi & 8 orang \\
\hline & Total & & 24 orang \\
\hline
\end{tabular}

Sumber: data diolah

Tahap pembedengan dan pembuatan parit perlu dipersiapkan dengan lahan yang tersedia sebagaimana tercantum dalam buku Panduan Budidaya Tanaman Sayuran ( Susila Ana D 2006 ).sesuai dengan ketentuan tersebut dan kriteria ukuran yang ideal untuk masing - masing jenis tanaman sayuran perlu diwujudkan sehingga dapat diketahui lahan efektip secara terperinci hal ini akan lebih mempermudah persiapan maupun pengerjaan dapat dilakukan dengan baik dan dapat dipersiapkan berapa jumlah bedeng, kebutuhan benih,berapa kebutuhan pupuk maupun jenisnya dan kapan waktu pemberiaan pupuk diberikan pada lahan garapan.Tentang ukuaran bedeng dan parit untuk aneka jenis tanaman sayuran,kebuthan bibit,kebutuhan pupuk serta waktu pemupukan sebagai berikut

Tabel 4.3. Jenis Tanaman Dan Pembagian Lahan Efektif Penggarapan Lahan Pilot Proyek

\begin{tabular}{|l|l|l|l|l|}
\hline No & $\begin{array}{l}\text { Jenis Tanaman dan } \\
\text { luas lahan }\end{array}$ & $\begin{array}{l}\text { Ukuran ideal } \\
\text { bedeng dan parit }\end{array}$ & Volume & $\begin{array}{l}\text { Luas lahan } \\
\text { efektip }\end{array}$ \\
\hline 1 & $\begin{array}{l}\text { Kangkungdarat } \\
\text { lahan:10X20m=200m }\end{array}$ & $\begin{array}{l}\text { Bedeng:1 X 19 m } \\
\text { Parit1 :0,5 X 19 m } \\
\text { Parit2: 1X10m }\end{array}$ & 6,67 unit & $126 \mathrm{~m}$ \\
\hline 2 & $\begin{array}{l}\text { Bayam cabut } \\
\text { lahan:15X10m=150m }\end{array}$ & $\begin{array}{l}\text { Bedeng 1X15m } \\
\text { Parit 0,5 X 15 M }\end{array}$ & 10 Unit & $100 \mathrm{~m}$ \\
\hline 3 & $\begin{array}{l}\text { Terong } \\
\text { lahan:18X20m=360m }\end{array}$ & $\begin{array}{l}\text { Bedeng 1X20m } \\
\text { Parit 0,5 X 20m }\end{array}$ & 12 Unit & $240 \mathrm{~m}$ \\
\hline 4 & $\begin{array}{l}\text { Kacang panjang } \\
\text { lahan:20X20m=200m }\end{array}$ & $\begin{array}{l}\text { Bedeng 1X20 m } \\
\text { Parit 0,5X20m }\end{array}$ & 13 Unit & $260 \mathrm{~m}$ \\
\hline & Total lahan efektip & & & $726 \mathrm{~m}$ \\
\hline
\end{tabular}

Sumber : Data primer diolah

Tabel 4.4. Kebutuhan Bibit Setiap Luas Lahan Efektif Penggarapan Pilot Proyek

\begin{tabular}{|l|l|l|l|l|}
\hline No & Jenis Tanaman & Kebutuhan Bibit/ Ha. & $\begin{array}{l}\text { Luas Lahan } \\
\text { Efektip }\end{array}$ & $\begin{array}{l}\text { Kebutuhan } \\
\text { Bibit }\end{array}$ \\
\hline 1 & Kangkung darat, & $5-10 \mathrm{Kg}$ ? Ha & $126 \mathrm{~m}$ & $126 \mathrm{Gram}$ \\
\hline
\end{tabular}




\begin{tabular}{|l|l|l|l|l|}
\hline 2 & Bayam cabut & $5-10 \mathrm{Kg} / \mathrm{Ha}$ & $100 \mathrm{~m}$ & $100 \mathrm{Gram}$ \\
\hline 3 & Terong & $150-500 \mathrm{Gram} / / \mathrm{Ha}$ & $240 \mathrm{~m}$ & $12 \mathrm{Gram}$ \\
\hline 4 & Kacang panjang & $20 \mathrm{Kg} / \mathrm{Ha}$ & $260 \mathrm{~m}$ & $520 \mathrm{Gram}$ \\
\hline
\end{tabular}

Sumber : Data primer diolah

Tabel 4.5. Kebutuhan Pupuk, Waktu Pemupukan Dan Jenis Pupuk Setiap Luas Lahan Efektif Penggarapan Pilot Proyek

\begin{tabular}{|c|c|c|c|c|c|}
\hline No & $\begin{array}{l}\text { Jenis } \\
\text { tanaman }\end{array}$ & Waktu & Urea dan pupuk cair & SP.36 & KCL \\
\hline 1 & $\begin{array}{l}\text { Kangkung } \\
\text { darat }\end{array}$ & $\begin{array}{l}\text { Preplant } \\
\text { 3MST }\end{array}$ & $\begin{array}{r}126 / 10.000 X 187 \mathrm{Kg}=2,4 \mathrm{Kg} \\
\times 187 \mathrm{~kg}=2,4 \mathrm{Kg}\end{array}$ & $311 \mathrm{~kg}=4 \mathrm{~kg}$ & $\begin{array}{l}112 \mathrm{~kg}=1,5 \mathrm{~kg} \\
112 \mathrm{~kg}=1,5 \mathrm{Kg}\end{array}$ \\
\hline 2 & $\begin{array}{l}\text { Bayam } \\
\text { cabut }\end{array}$ & $\begin{array}{l}\text { Preplant } \\
2 \text { MST }\end{array}$ & $\begin{array}{l}100 / 10.000 X 150 \mathrm{Kg}=1,5 \mathrm{Kg} \\
100 / 10.000 X 3 \text { Liter }=0,03 \\
\text { liter }\end{array}$ & $\begin{array}{l}- \\
-\end{array}$ & - \\
\hline 3 & Terong & $\begin{array}{l}\text { Preplant } \\
\text { 2MST } \\
5 \mathrm{MST} \\
7 \mathrm{MST}\end{array}$ & $\begin{array}{r}240 / 10.000 X 160 \mathrm{~kg}=3,84 \mathrm{Kg} \\
80 \mathrm{~kg}=1,9 \mathrm{~kg} \\
80 \mathrm{~kg}=1.9 \mathrm{~kg} \\
80 \mathrm{~kg}=1.9 \mathrm{~kg}\end{array}$ & - & $\begin{array}{l}90 \mathrm{~kg}=2.2 \mathrm{~kg} \\
45 \mathrm{~kg}=1.1 \mathrm{~kg}- \\
45 \mathrm{~kg}=1.1 \mathrm{~kg} \\
45 \mathrm{~kg}=1.1 \mathrm{~kg}\end{array}$ \\
\hline 4 & $\begin{array}{l}\text { Kacang } \\
\text { panjang }\end{array}$ & $\begin{array}{l}\text { Preplant } \\
3 \mathrm{MST}\end{array}$ & $\begin{aligned} 260 / 10.000 X 112 \mathrm{~kg} & =3 \mathrm{~kg} \\
112 \mathrm{~kg} & =3 \mathrm{~kg}\end{aligned}$ & $\begin{array}{l}250 \mathrm{~kg}=6.5 \mathrm{k} \\
\mathrm{g} \\
-\end{array}$ & $\begin{array}{l}90 \mathrm{~kg}=2.4 \mathrm{~kg} \\
90 \mathrm{~kg}-2.4 \mathrm{~kg}\end{array}$ \\
\hline & Total & & $21.84 \mathrm{~kg}+0,03$ liter cair & $10.5 \mathrm{~kg}$ & $13.3 \mathrm{~kg}$ \\
\hline
\end{tabular}

Sumber : Data primer diolah

Pemeliharaan dan Pemanenan Aneka jenis Tanaman Sayuran :

1. Tanaman Sayuran Kangkung Darat :

Pemeliharaan ;

$>\quad$ Kangkung darat sebaiknya ditanam pada saat sore hari .

$>\quad$ Penyiraman dilalukan secara rutin $2 \mathrm{X}$ sehari pagi dan sore hari terutama pada saat musim kemarau.

$>\quad$ Penjarangan dan penyulaman dilakukan

$>\quad$ Penyiangan dilakukan setiap dua minggu sekali

$>\quad$ Agar pertumbuhan subur sebaiknya seminggu setelah dipanen tanaman dipupuk kembali.

Panen :

$>\quad$ Panen dilakukan sore hari dengan mencari batang yang besar dan dun yang lebar

$>\quad$ Panen pertama dilakukan pada hari ke 12 dengan batang tnggi sekitar $25 \mathrm{Cm}$

$>\quad$ Cara memanen dengan alat potong dengan menyisakan batang sekitar $5 \mathrm{Cm}$ atau dicabut sampai akarnya

$>\quad$ Lahan harus tetap lembab

$>\quad$ Panen rutin dilakukan setian 2-3 minggu sekali.

$>\quad$ Panenan sekitar 15-20 batang per ikatSebelum dipasarkan atau dikionsumsi kangkung ikatan sebaiknya dicelupkan didalam air bersih kemudian ditiriskan.

2. Tanaman sayuran Bayam Cabut : Pemeliharaan :

$>\quad$ Penyiangan dilakukan 2 Minggu Seteelah Tanam (MST) 
$>\quad$ Setiap 2 Minggu dilakukan penggemburan dan pemberian pupuk susulan dan penyiangan.

Panen :

$>\quad$ Penjarangan dilakukan 20 Hari Setelah Tanam (HST)

$>\quad$ Panenan berikutnya setiap 25 - 30 hari sekali

$>\quad$ Dan seterusnya sampai habis

$>\quad$ Sebelum dipasarkan panenan diikat antara 15- 20 batang .

3. Tananaman Sayuran Terong ;

Pemeliharaan ;

$>\quad$ Penanaman dilakukan setelah bibit berumur 1,5 bulan atau setelah mempunyai daun sekitar 4 lembar

$>\quad$ Penyulaman dilakukan pada tanaman tidak sehat 1 MST dengan bibit yang sehat dan sepadan

$>\quad$ Penyajiran dilakukan 1 MST

$>\quad$ Ajir dari belhan bambu dengan tinggi 0,9 $\mathrm{M}$ dan Lebar sekitar $3 \mathrm{CM}$ dengan jarak ajir dan pohon sekitar $6 \mathrm{CM}$.

$>\quad$ Pengikatan ajir dengan pohon 3 MST dengan raffia.

$>\quad$ Perampalan pada pucuk percabangan setelah pohon memiliki 12 daun.

$>\quad$ Penyiangan dan pemumukan tambahan dilakukan 15 HST dengan susulan pemupukan tambahan dan selanjutnya 60-75 HST jarak 20-25 Cm dari batang tanaman larikan.

$>\quad$ Penyiraman dilakukan sesaat setelah tanam dan seterusnya stiap 3 hari sekali sebaiknya pada sore hari.dan apabila hampir berbunga penyiraman dilakukan 2 hari sekali.

Panen

$>\quad$ Panenan pertama dilakukan setelah tanaman berumur 70-80 hari seterusnya setiap 37 hari sekali terong dapat dipanen hingga 13- 15 kali.

4. Tanaman Sayuran Kacang Panjang Pemeliharaan

$>\quad$ Jarak tanam dari satu lubang ke lubang berikutnya $25-30 \mathrm{Cm}$ dengan kedalaman 4-5 Cm jarak antar baeis 60- $75 \mathrm{Cm}$ tiap lubang diisi 2butir biji kemudian ditutup tanah tipis.

> Penyiraman 1 MST selanjutnya sehari $2 \mathrm{X}$ pagi dan sore terutama pada musi kemarau.

Penyiangan dilakukan 3 dan 6 MST dan dilakukan pendangiran

$>$

Pemasangan turus untuk merambatkan batang tanaman dengan belahan bambu ukuran tinggi $2 \mathrm{M}$ lebar $3 \mathrm{CM}$ pemasangan dilakukan pada umur $2 \mathrm{MST}$ atau tinggi sekitar $25 \mathrm{Cm}$.

$>\quad$ Pemangkasan pucuk cabang dilakukan $1 \mathrm{X}$ pada 3 MSTdengan memotong pucuk 3 ruas.

Panen

$>\quad$ Tanaman mulai berbunga pada umur sekitar 30 hari

$>\quad$ Panenan pertama dilakukan pada saat polong muda Kacang panjang terisi penuh dan warnanya sudah sampai hijau merata menaji memutih. Dengan cara dipetik.

Melihat antusiasme masyarakat yang dicerminkan oleh peserta kegiatan pengabdian masyarakat sejumlah 24 orang setelah diskusi selesai semua peserta mendatangi lahan dan sekaligus untuk membuktikan luas lahan garapan pilot proyek dengan mengukur secara serius dan dihari berikutnya dalam minggu pertama melakukan penebangan pohon yang menghalangi sinar matahari dan batang hasil tebangan dijual sebagai modal awal untuk 
menggarap pengolahan lahan awal dengan melakukan penyemprotan gulma rumput agar mati dan kemudian dilakukan pembakaran rumpit atau gulma yang sudah kering.Seminggu kemudian akan dilakukan pengolahan lahan dengan traktor tangan dan dicangkul sekaligus menyingkirkan gulma - gulma yang masih tersisa.dan tahap - tahap pengerjaan berikutnya seluruh peserta masih dan terus setia melibatkan diri dengan partisipasi aktif.

\section{Evaluasi}

Setelah kegiatan pengabdian kepada masyarakat dilakukan tim mengharapkan adanya perubahan perilaku masyarakat dari tidak memperdulikan lahan pekarangannya dengan membiarkan lahan menganggur,kumuh dan tidak mendatangkan manfaat apapun berubah menjadi perilaku produktif yaitu mulai adanya kepedulian terhadap lahannya untuk digarap secara produktif dengan cara menanami berbagai tanaman yang secara ekonomi mendatangkan hasil minimal untuk mencukupi kebutuhan pribadi akan gizi,maupun keasrian lingkungan tempat tinggal sehingga terlihat indah dan nyaman,apalagi kalau dikelola secara baik dan profesional akan bisa mendatangkan pendapatan selain juga membuka kesempata kerja bagi masyarakat lingkungan maupun secara multipliyer dapat memunculkan pedagang sayuran atau buah - buahan hasil nyata atas pengoptimalan penggunakan lahan pribadi secara produktif inilah yang harus menjadikan capaian sasaran dari kegiatan pengabdian yang dilakukan oleh Tim Pengabdian Kepada Masyarakat di Desa Denggungan, Kecamatan Banyudono Kabupaten Boyolali hal ini dapat dikatakan berhasil atau tidak berhasil dapat dilihat dari diskripsi dari respon peserta maupun masyarakat

. Tabel 4.6. Kriteria dan Indikator Tingkat Keberhasilan Kegiatan Pengabdian

\begin{tabular}{|l|l|l|}
\hline No & Kriteria & Indikator \\
\hline 1 & $\begin{array}{l}\text { Tingkat } \\
\text { Ketertarikan }\end{array}$ & $\begin{array}{l}\text { Kegiatan pengabdian diikuti peserta yang terdiri dari unsur } \\
\text { Pamong, Pengurus LPMD,Pengurus RT, Pengurus PKK dan } \\
\text { masyarakat umum yang secara suka rela menyediakan diri untuk } \\
\text { hadir sejumlah 24 orang. }\end{array}$ \\
\hline 2 & $\begin{array}{l}\text { Tingkat Partisipasi } \\
\text { dalam pilot proyek } \\
\text { pemanfaatan lahan }\end{array}$ & $\begin{array}{l}\text { Ada penduduk yang secara sukarela meminjamkan lahan } \\
\text { pekarangannya untu dijadikan lahan sebagai proyek } \\
\text { percontohan untuk ditanami sayuran selain juga terdapat } \\
\text { antusiasme peserta terlibat sebagai kader penggerak } \\
\text { pengoptimalan pemanfaatan lahan pekarangan }\end{array}$ \\
\hline 3 & Target /Sasaran & $\begin{array}{l}\text { Dengan dilakukannya percontohan penggarapan lahan } \\
\text { pekarangan diharapkan setelah melihat bukti nyata bahwa } \\
\text { ternyata lahan yang digarap secara produktif mampu } \\
\text { memberikan solusi atas berbagai masalah yang dirasakan } \\
\text { masyarakat,dengan demikian sudah ada sebagian masyarakat } \\
\text { mengikuti secara sadar menggarap lahannya untuk ditanami } \\
\text { berbagai tanaman holtikultura dan budidaya tanaman lainnya dari } \\
\text { sebelumnya lahan dibiarkan menganggur. }\end{array}$ \\
\hline
\end{tabular}

\section{Kesimpulan}

Hasil pengabdian ini menunjukkan bahwa:

1. Pembuatan Pilot proyek Pemanfaatan lahan pekarangan dengan tanaman sayuran dapat diwujudkan di Desa Denggungan Kecamatan Banyudono Kabupaten Boyolali.

2. Sebagian Masyarakat secara sukarela menyediakaan diri sebagai kader penggerak dalam memotivasi masyarakat lainnya untuk memanfaatan lahan pekarangannya untuk berbagai tanaman hortikultura. 
3. Untuk Percotohan sementara baru diuji cobakan 4 jenis tanaman sayuran yaitu Kangkung darat,Bayam cabut ,Terong dan Kacang Panjang

\section{E. Daftar Pustaka}

Balai Pengkajian Teknologi Pertanian Yogyakarta. 2012. Penyiraman sayuran vertikultur sistem irigasi selang (SIS). Berita Badan Litbang Pertanian. www.litbang.deptan/berita, 23 Oktober 2012.

Balai Pengkajian Teknologi Pertanian Sulawesi Utara. 2012. Kawasan rumah pangan lestari atas II Kecamatan Sonder, bantu kebutuhan harian keluarga. Berita Badan Litbang Pertanian. www.litbang.deptan/berita, 23 Oktober 2012.

Dirjen Hortikultura. 2010. Pedoman Umum Pelaksanaan Pengembangan Hortikultura Tahun 2010. Badan Litbang Pertanian.

Hanani N. 2012. Strategi pencapaian ketahanan pangan keluarga. Agricultural Economics Electronic Journal. 1 (1) : 5-15.

Mahela, Sutanto. 2006. Konsep ketahanan pangan. Jurnal Protein. 13(2):10-21.

Mardiharini M. 2011. Model kawasan rumah pangan lestari dan pengembangannya ke seluruh provinsi di Indonesia. Warta Penelitian dan Pengembangan Pertanian 33 (6): 3-5.

Nurcahyati E., 2012. Membangun kemandirian pangan melalui pemanfaatan lahan pekarangan. Badan Ketahanan Pangan Propinsi Banten.

Rukmana, R. 2009. Bertanam Sayuran di Pekarangan, Cetakan 5 tahun 2009. Penerbit Kanisius Yogyakarta.

Saliem H.P. 2011. Kawasan Rumah Pangan Lestari (KRPL): Sebagai Solusi Pemantapan Ketahanan Pangan

Setyaningru, H. D., dan Saparinto, C. 2011. Panen Sayuran Secara Rutin di Lahan Sempit. Penebar Swadaya, Jakarta.

Supriati, Y., dan Herliana, E. 2010. Bertanam 15 Sayuran Organik dalam Pot. Penebar Swadaya, Jakarta. 156.

Susila Ana D2006,Panduan Budidaya TanamanSayuran,Bogor 